\title{
Productivity and nutrition of fertigated açaí palms according to boron fertilization
}

\author{
Marcelo Morita Lindolfo ${ }^{1}$, Gilson Sérgio Bastos de Matos², \\ Wendel Valter da Silveira Pereira ${ }^{3}$, Antonio Rodrigues Fernandes ${ }^{4}$
}

Abstract - Due to the increasing national and international demand, the cultivation of açaí palm trees (Euterpe oleracea Mart.) has expanded to upland areas in Brazil. Most of these areas present low natural soil fertility, in which boron (B) is one of the most limiting nutrients. This study aimed to evaluate the productivity of fresh fruits of fertigated açaí trees submitted to doses of B. The study was carried out in Tomé-Açu, northeastern Pará, Brazil. The experimental design consisted of randomized blocks with four treatments: control and addition of 20,40 and $60 \mathrm{~g}$ of $\mathrm{B} \mathrm{clump}^{-1}$. After 17 months, bunches of fresh fruits were collected and the production per hectare was estimated. An economic analysis was carried out considering the costs of fertilization and fruit production. The productivities obtained in the treatments were considered above the average of the municipality of Tomé-Açu. The estimated content of leaf B that provided the highest productivity was $14.9 \mathrm{mg} \mathrm{kg}^{-1}$, for a yield of $5479 \mathrm{~kg} \mathrm{ha}^{-1}$ year $^{-1}$, while the critical content corresponded to $13.2 \mathrm{mg} \mathrm{kg}^{-1}$. The highest productivity of fresh açaí fruits was achieved with the dose of $20 \mathrm{~g}$ of $\mathrm{B}_{\text {clump }}{ }^{-1}$, which provided a net gain of $42 \%$.

Index terms Euterpe oleracea Mart., doses of boron, fertigation, northeastern Pará.

\section{Produtividade e nutrição de açaizeiros fertirrigados em função da adubação com boro}

Corresponding author: morita.agroeco@agronomo.eng.br

Received: June 24, 2019 Accepted: January 31, 2020

Copyright: All the contents of this journal, except where otherwise noted, is licensed under a Creative Commons Attribution License.

\section{(cc) $\mathbf{E Y}$}

Resumo - Por conta do aumento da demanda nacional e internacional, o cultivo do açaizeiro (Euterpe oleracea Mart.) tem-se expandido para áreas de terra firme no Brasil. Muitas destas áreas apresentam baixa fertilidade do solo, onde o boro (B) é um dos nutrientes mais limitantes. O objetivo foi avaliar a produtividade de frutos frescos de açaizeiros submetidos a doses de B em plantio fertirrigado, no município de Tomé-Açu, nordeste paraense, Brasil. O delineamento experimental foi em blocos ao acaso, com quatro tratamentos: controle e adição de 20; 40 e $60 \mathrm{~g}^{\text {touceira }}{ }^{-1}$ de B. Após 17 meses, foram coletados os cachos de frutos frescos e a estimada produção por hectare. Foi realizada uma análise econômica considerando os custos de adubação e a produção de frutos. As produtividades obtidas nos tratamentos estão acima da média do município de Tomé-Açu. O teor estimado de $\mathrm{B}$ foliar, que proporcionou a maior produtividade, foi igual a 14,9 $\mathrm{mg} \mathrm{kg}^{-1}$, para uma produtividade de $5.479 \mathrm{~kg} \mathrm{ha}^{-1}$ ano $^{-1}$, enquanto o teor crítico correspondeu a $13,2 \mathrm{mg} \mathrm{kg}^{-1}$. A maior produtividade de frutos frescos de açaí foi atingida com a dose de $20 \mathrm{~g}_{\text {touceira }}{ }^{-1} \mathrm{de} \mathrm{B}$, a qual proporcionou ganho líquido de $42 \%$.

Termos para indexação: Euterpe oleracea Mart., doses de boro, fertirrigação, nordeste paraense.

\footnotetext{
${ }^{1}$ Agronomist, Master in Agronomy, Kasuya Agronomic Intelligence, E-mail: morita.agroeco@agronomo.eng.br (ORCID: 0000-0002-1011-6993)

${ }^{2}$ Agronomist, Assistant Professor, Institute of Agricultural Sciences, Federal Rural University of Amazon, E-mail: gilson.matos@ufra.edu.br (ORCID 0000-0002-0846-0314)

${ }^{3}$ Forest Engineer, Master in Agronomy, Institute of Agricultural Sciences, Federal Rural University of Amazon, E-mail: wendelvalter@gmail. COm (ORCID 0000-0002-7958-6758)

${ }^{4}$ Agronomist, Titular Professor, Institute of Agricultural Sciences, Federal Rural University of Amazon, E-mail: antonio.fernandes@ufra.edu.br ${ }^{\text {(ORCID: }}$ 0000-0001-6270-3930)
} 


\section{Introduction}

The açaí palm (Euterpe oleracea Mart.) is a species of palm tree native to the Brazilian Amazon. The fruit became a staple food in floodplain areas, which can be consumed in natura and/or juices, in addition to being a source of raw material for the heart of palm industry (ARAUJO et al., 2016). In 2016, the national production of açaí was over 1,200,000 t, with the state of Pará as the main producer, with $94 \%$ of national production, involving an area of more than 219,000 ha in upland crops and extracted from lowland areas (IBGE, 2017). The growth of national and international demand for açaí juice has led to a great expansion of cultivation in irrigated land areas.

In the state of Pará, açaí trees are cultivated mainly in Yellow Latosol of low natural fertility, which makes the proper management of fertilization essential to achieve high productivity. Therefore, it is necessary to know the nutritional requirements, as well as the nutrients that most limit the cultivation on dry land. Studies carried out in the state of Pará revealed a nutrient requirement by açaí plants as follows: $\mathrm{N}>\mathrm{K}>\mathrm{S}>\mathrm{Ca}>\mathrm{Mg}>\mathrm{P}>\mathrm{Mn}>\mathrm{Zn}>$ $\mathrm{B}>\mathrm{Cu}$ (ARAUJO et al., 2016). In northeastern Pará, the cultivation of açaí on dry land has increased over the years. However, nutrients such as manganese $(\mathrm{Mg})$, calcium $(\mathrm{Ca})$ and boron (B) have shown a high frequency of deficiency in areas where fertigation is carried out (RIBEIRO, 2017).

Excessive fertilization with $\mathrm{B}$ is known to decrease the productivity of agricultural production (AQUEA et al., 2012; KAYIHAN et al., 2016; HAMURCU et al., 2019; NAZIR et al., 2019). In açaí trees in the state of Pará, fertilization with B has been randomly adopted, which negatively affects production (RIBEIRO, 2017). The importance of $\mathrm{B}$ in açaí palm nutrition has been evidenced from deficiency symptoms, as well as reduced height and diameter (VIÉGAS et al., 2008; VIÉGAS et al., 2009). These reductions are related to the role of $B$ in meristematic growth, functioning of cell membranes and ATPase activity (MARSCHNER, 2012). In oil palm (Elaeis guineensis) and coconut, deformed and wrinkled leaves and lower productivity are also attributed to B deficiency (SOBRAL, 1998; VIÉGAS et al., 2004).

Due to the high demand for B by the plants of the Arecaceae family (BROSCHAT, 2007) and the dynamics of the element in the soil, it is important to control the application of B, especially in soils that have low concentration available. Since B is considered a micronutrient, the limit between adequate contents and toxicity for plants is very narrow (MASOOD et al., 2019), which reinforces the need to define the appropriate dose (BRUNES et al., 2016). In açaí palms, the definition of the appropriate dose of B is essential for increasing productivity, low environmental impact and greater profitability. In this context, this study aimed to evaluate the productivity and mineral nutrition of açaí palm trees submitted to doses of B in fertigated cultivation.

\section{Material and methods}

The study was implemented in a plot of commercial planting area, considered as a model of a local agricultural cooperative, in Tomé-Açu, northeast of Pará, Brazil $\left(02^{\circ} 28^{\prime} 43.6^{\prime \prime} \mathrm{S}\right.$ and $\left.48^{\circ} 18^{\prime} 16.8^{\prime \prime} \mathrm{W}\right)$ (Figure 1). The seedlings were formed from seeds of native plants and had $45 \mathrm{~cm}$ when acquired at eight months of age. At the beginning of the experiment, the plants were eight years old (productive phase) and were spaced $5 \times 5 \mathrm{~m}$ apart.
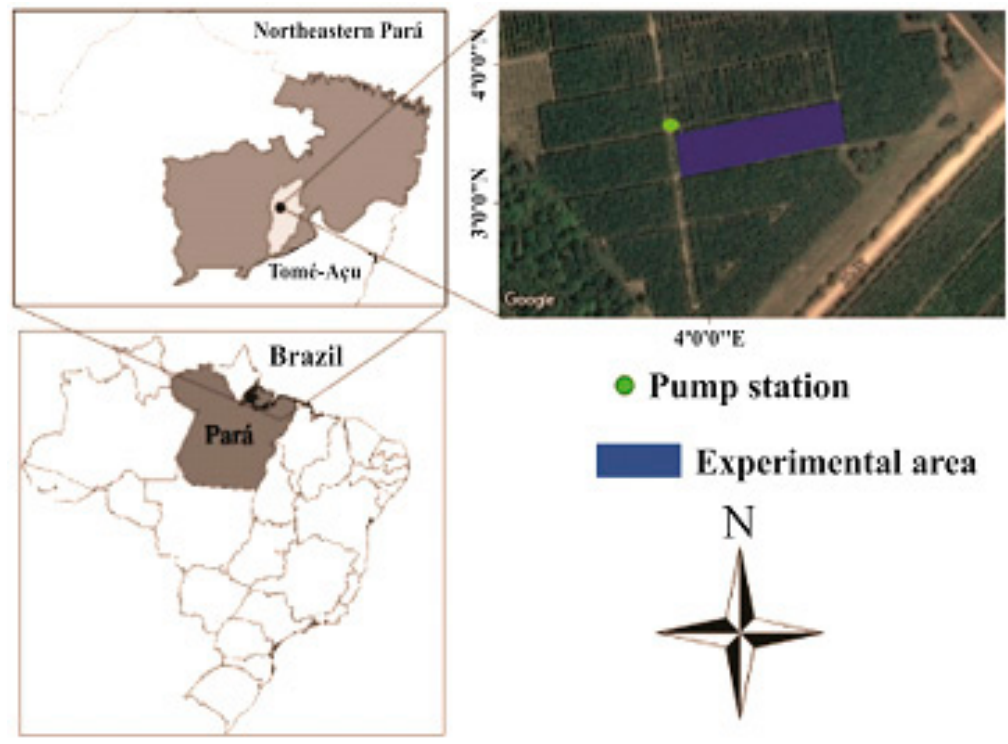

Figure 1. Planting of fertigated açaí palm trees and pump station for irrigation. 
According to the Köppen classification, the predominant climate of the region is Ami, with an average temperature of $26.4{ }^{\circ} \mathrm{C}$, ranging between 22 and $33{ }^{\circ} \mathrm{C}$, relative air humidity ranging between 71 and $91 \%$ and average rainfall of $2405 \mathrm{~mm}$, concentrated from December to May (Figure 2). The soil of the area was classified as medium-texture Dystrophic Latosol (SANTOS et al., 2018). At the time of planting, $200 \mathrm{~g}$ of reactive phosphate $\left(10 \% \mathrm{P}_{2} \mathrm{O}_{5}\right.$ soluble in citric acid and $30 \%$ total $\left.\mathrm{P}_{2} \mathrm{O}_{5}\right)$ were used per plot. During the initial five years of cultivation, 40, 112 and $80 \mathrm{~g}^{-1}$ clump $^{-1}$ year ${ }^{-1}$ of $\mathrm{N}, \mathrm{P}_{2} \mathrm{O}_{5}$ and $\mathrm{K}_{2} \mathrm{O}$ were applied, respectively, by manual fertilization. From the 5 th year on, fertigation with water-soluble fertilizers was carried out.

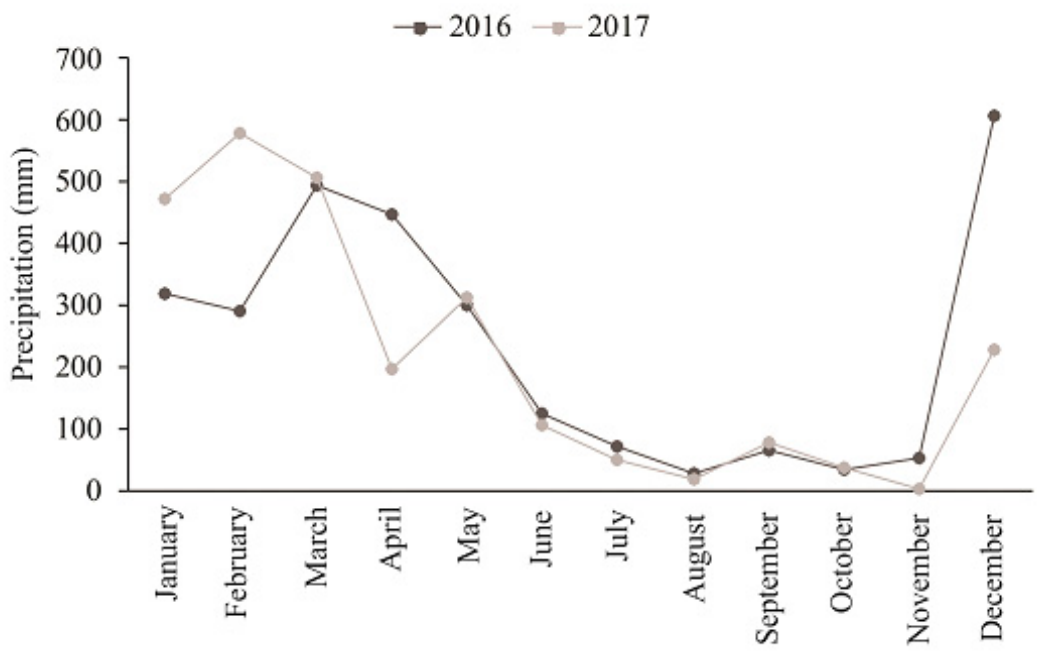

Figure 2. Average monthly rainfall between 2016 and 2017 in the municipality of Tomé-Açu (automatic station INMET A236 - Cametá), northeastern Pará, Brazil. Source: National Institute of Meteorology - INMET (2019).

To supply the water demand of the plants during the dry season, irrigation was carried out from the 5th year of cultivation. The distribution system consisted of micro sprinklers with an application intensity of 2.8 $\mathrm{mm} \mathrm{h}^{-1}\left(70 \mathrm{~L} \mathrm{~h}^{-1}\right.$ of water) and an irrigation time of $1 \mathrm{~h}$ and $30 \mathrm{~min}$, which provided $105 \mathrm{~L}$ of water per clump, considering the effective root at $30 \mathrm{~cm}$ depth after field observation. The water supply met $84 \%$ of the maximum evapotranspiration. The irrigation system, in the absence of parameters for the culture, was dimensioned based on empirical parameters, considering the maximum local evapotranspiration of $5 \mathrm{~mm} \mathrm{day}^{-1}$ and the culture coefficient (Kc) equal to 1 .
Fertigation was performed weekly in a programmed application that comprised fractions of the total nutrients, totaling 52 annual applications. This period included an application every seven days, from January to December. The injections of the fertilizer solution were performed with a multistage pump model Booster of $1 \mathrm{hp}$, in order to avoid loss of loads in the system and unevenness during application.

The nutrient doses were defined according to the fertilization recommendation bulletin for the region (CRAVO et al., 2007). Although the recommendations are for solid fertilization, the nutrient contents were met through fertilizers with good solubility, suitable for fertigation (Table 1).

Table 1. Sources and doses of nutrients used in fertigation.

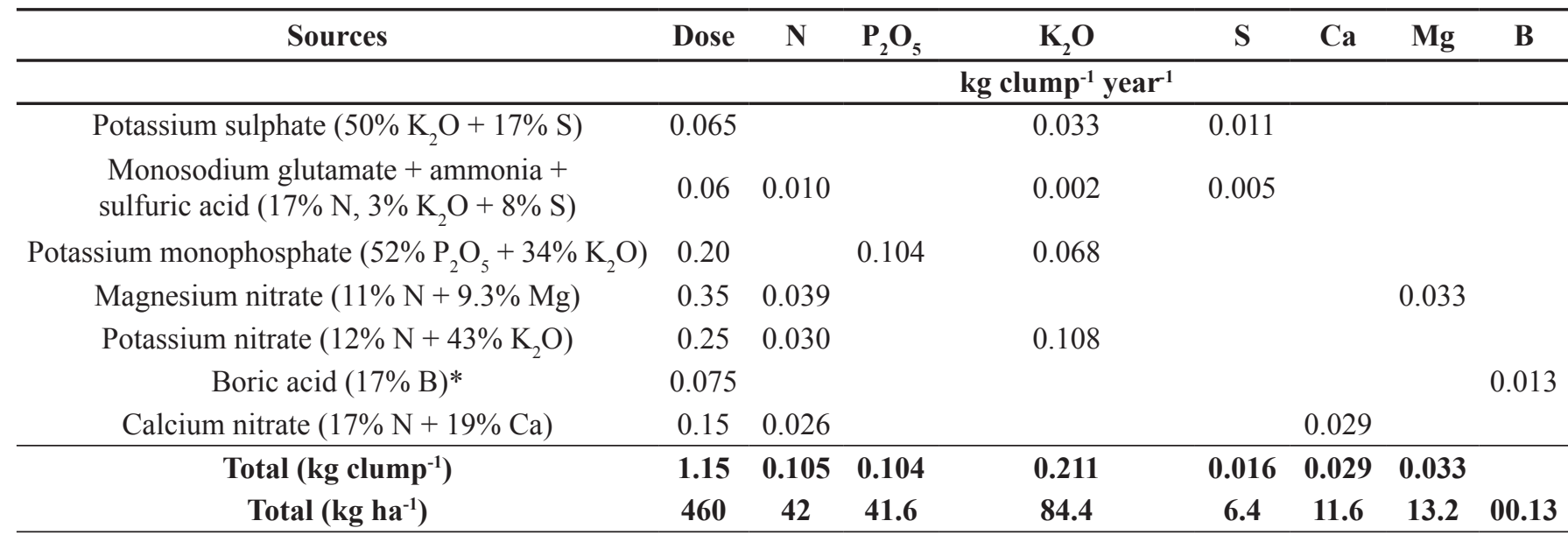

\footnotetext{
*Eliminated from fertigation when starting treatment with boron in the soil.
} 
Fertilization with $\mathrm{B}$ was eliminated from fertigation in the experimental area in the last week of March 2016 (one month before starting the treatments). Fertilization with B was carried out using borax fertilizer $(10 \% \mathrm{~B})$, provided in a fractionated and manual form in three applications, except for the control treatment, during the rainy season.

The experimental design consisted of randomized blocks with four treatments: control (T1 - without B addition) and doses of B of 20 (T2), 40 (T3) and 60 (T4) $\mathrm{g}$ of $\mathrm{B}$ clump $^{-1}$. There were five repetitions and 16 clumps constituting each plot. Surrounding plants were removed from soil. Only the four clumps in the center of the plot were considered as useful plants.

Leaf samples were collected from the four useful clumps of each experimental unit. The average leaf number (counting from top to bottom) was taken as a reference or diagnosis, corresponding to the number six leaves as the median portion of a total of 12 leaves, always in the third dominant stump of the clump, totaling 20 samples composed for each experimental unit. Similarly, the soil samples consisted of samples composed of the four clumps of each experimental unit, with a depth of 0 to $20 \mathrm{~cm}$, totaling 20 samples.

Soil and leaf sampling were performed in January 2016, before treatment with B. A second sampling was carried out in November 2017, after 17 months of the last application of $\mathrm{B}$. This interval is the time required for fruit formation (JARDIM; ANDERSON, 1987; OLIVEIRA et al., 1998; OLIVEIRA et al., 2002).

The clusters of fresh fruit from the four clumps of the areas considered to be useful were harvested, threshed and weighed in November and December 2017 and January 2018. Each clump occupied an area of $25 \mathrm{~m}^{2}$, thus, the four clumps occupied $100 \mathrm{~m}^{2}$. Considering these values, the production of fresh fruits of each treatment was estimated as $10,000 \mathrm{~m}^{2}$.

The harvest period was from November to January, which concentrates $85 \%$ of the annual production (November $=30 \%$, December $=30 \%$ and January $=25 \%$ ) (HOMMA et al., 2006), in an irrigated and productive açaí planting area in the municipality of Santo Antônio do Tauá, also northeastern Pará. Therefore, an additional $15 \%$ in production was added in order to estimate fruit production in $\mathrm{kg} \mathrm{ha}^{-1}$ year ${ }^{-1}$.

For the economic analysis, the price per $\mathrm{kg}$ of fresh açaí fruits paid by the local industry in the amount of R $\$ 1.50$ for the 2017/2018 harvest was considered. The cost of $\mathrm{kg}$ of borax commercial fertilizer (B 10\%) was R \$ 3.20 in the year of application (2017), in which the total cost of fertilizer used to obtain the highest productivity was R \$ 256 per hectare. Therefore, the cost for fresh fruits was $56.8 \mathrm{~kg}$ per application, in a total of $170 \mathrm{~kg}$ year-1. The application cost was not included because this value will disappear, as it will be applied together with the other fertilizers via fertigation.

The plant material was submitted to digestion with sulfuric acid solution to determine the content of nitrogen $(\mathrm{N})$ and nitroperchloric content for the other nutrients, except B. The boron content, after dry digestion, was determined by colorimetry (Azomethine- $\mathrm{H}$ method). Nitrogen was determined by distillation by the Kjeldahl method, while $\mathrm{Ca}, \mathrm{Mg}, \mathrm{Fe}, \mathrm{Mn}, \mathrm{Cu}$ and $\mathrm{Zn}$ were determined by atomic absorption spectrometry and $\mathrm{S}$ by turbidimetry (MALAVOLTA et al., 1997).

The $\mathrm{pH}$ of the soil was obtained in the 1:2.5 soil/ $\mathrm{CaCl}_{2}$ ratio. The organic carbon was obtained by the Walkley and Black method, multiplying by 1.72 to obtain the organic matter contents. Analyzes of P, K, Cu, Fe, Mn and $\mathrm{Zn}$ were carried out by the Mehlich-I solution and $\mathrm{Ca}$ and $\mathrm{Mg}$ by $1 \mathrm{~mol} \mathrm{~L}^{-1} \mathrm{KCl}$ solution. Sulfur was analyzed by calcium phosphate and $\mathrm{B}$ in hot water. The contents of sand, silt and clay were determined by the pipette method (SILVA, 2009) (Table 2).

The data were submitted to the KomolgorovSmirnov test, which confirmed normal distribution. Then, data variance analysis was performed and, when significant by the $F$ test $(p<0.05)$, regression analysis was performed as a function of B doses for productivity, relationship between productivity and $\mathrm{B}$ content in leaves, nutrient content in the leaves and concentration of nutrients in the soil.

To express the behavior of the $\mathrm{B}$ doses, the model that best expresses the response of the evaluated characteristics was selected. In the regression, the linear and quadratic models were studied for the levels of macro and micronutrients in the leaf and the contents of micronutrients in the soil. The software Statistica 9.0 (STATSOFT, 2009) was used.

\section{Results and discussion}

The productivity of fresh fruits increased by 47 , 32 and 5\% when compared with the control treatment, with doses of 20, 40 and $60 \mathrm{~g}$ of B clump ${ }^{-1}$, respectively, adjusting to a quadratic function (Figure $3 \mathrm{~A}$ ). The productivity, including in the control treatment $(3765 \mathrm{~kg}$ $\left.\mathrm{ha}^{-1}\right)$ is above the average found for the municipality of Tomé-Açu, which corresponds to $3750 \mathrm{~kg} \mathrm{ha}^{-1}$ (SEDAP, 2018). The increase in fruit productivity is due to the role of B in the meristematic growth, as well as membrane function and ATPase activity (MARSCHNER, 2012), which influence plant growth and productivity. When in deficiency, it reduces the height and diameter of açaí seedlings (VIÉGAS et al., 2008; VIÉGAS et al., 2009), as well as the productivity of oil and coconut palms (RODRIGUES et al., 2006; SOBRAL, 1998). 

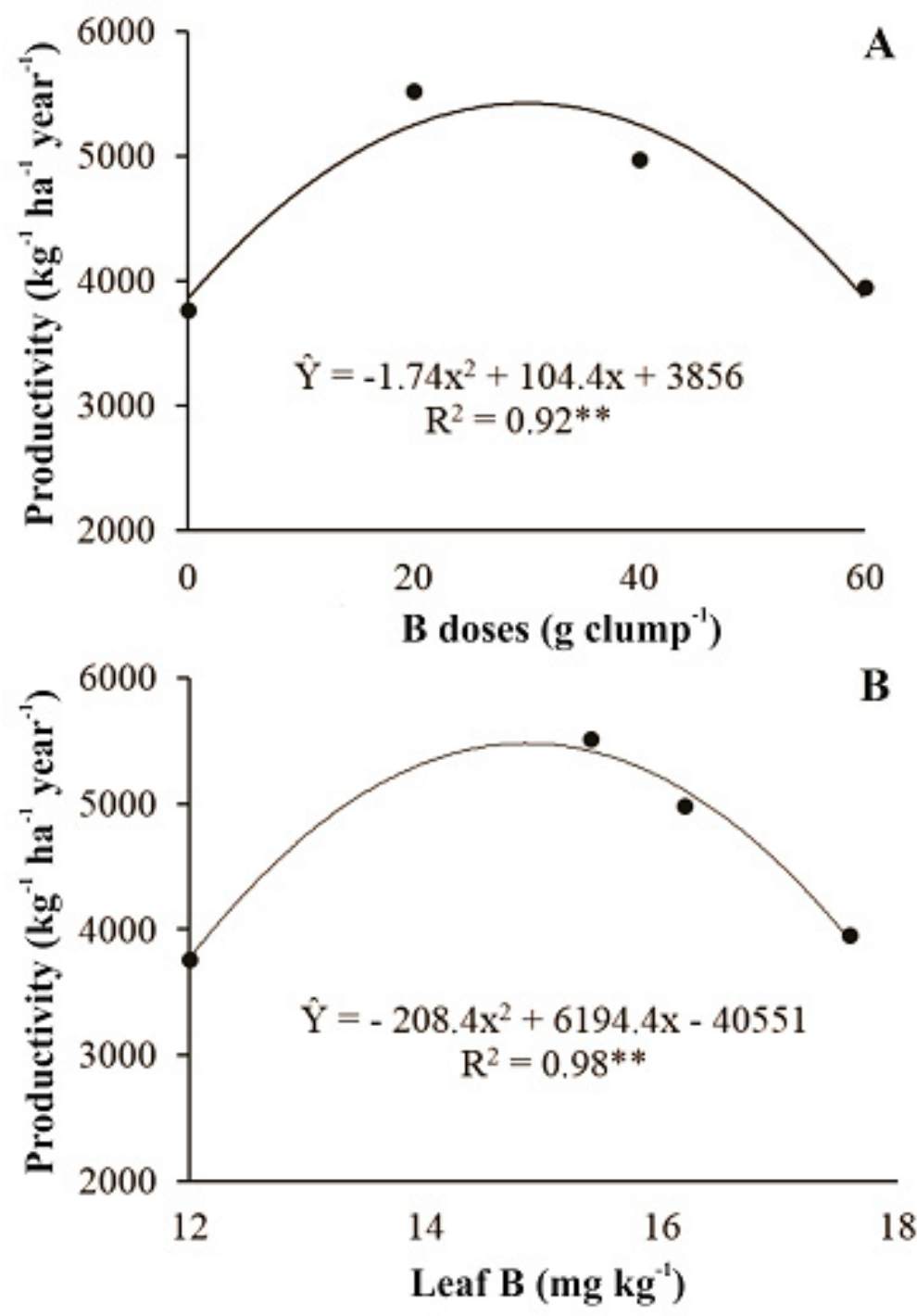

Figure 3. Productivity of fruits in response to doses of $\mathrm{B}(\mathrm{A})$ and relationship between the fruit production and leaf

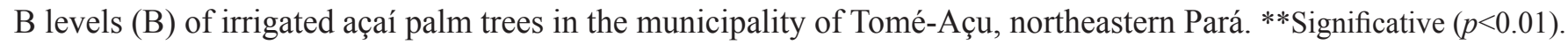

The highest productivity of fresh fruits $(5521 \mathrm{~kg}$ fertilization with B in productive açaí trees. Nevertheless, ha $^{-1}$ year $^{-1}$ ) was achieved with a dose of $20 \mathrm{~g}_{\text {of B clump }}{ }^{-1}, \quad$ it is reported the risks of toxicity in the field, especially with a reduction in productivity as the doses increased, in soils with high sand contents (PRADO, 2008), such as suggesting phytotoxicity. No studies were found on the of the present study (Table 2).

Table 2. Physical and chemical characterization of the soil and nutrient content in açaí palm trees in fertigated cultivation.

\begin{tabular}{|c|c|c|c|c|c|c|c|c|c|c|c|}
\hline \multicolumn{12}{|c|}{ Soil } \\
\hline $\mathrm{pH}$ & K & $\mathrm{Ca}$ & $\mathrm{Mg}$ & SB & CEC & $\mathrm{H}+\mathrm{Al}$ & V & $\mathrm{OM}$ & Sand & Silt & Clay \\
\hline \multirow[t]{2}{*}{$\mathrm{CaCl}_{2}$} & $--\cdot$ & 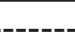 & $\begin{array}{c}----c \\
--c\end{array}$ & $\mathrm{dln}$ & ------- & ------- & $\%$ & \multicolumn{4}{|c|}{-------------------g dm³'------------------ } \\
\hline & 0.34 & 3.8 & 0.94 & $\stackrel{\mathrm{c}}{5.1}$ & 7.2 & 2.17 & 69.8 & 19.75 & 610 & 131.5 & 258.5 \\
\hline \multicolumn{2}{|l|}{$\mathrm{P}$} & \multicolumn{2}{|c|}{ B } & \multicolumn{2}{|c|}{$\mathrm{Cu}$} & \multicolumn{2}{|c|}{$\mathrm{Fe}$} & \multicolumn{2}{|c|}{$\mathrm{Mn}$} & \multicolumn{2}{|c|}{$\mathrm{Zn}$} \\
\hline & & & & & & \multicolumn{2}{|c|}{$m g \mathrm{~kg}^{-1}$} & & \multirow{2}{*}{\multicolumn{2}{|c|}{7.0}} \\
\hline \multicolumn{2}{|c|}{241} & \multicolumn{2}{|c|}{0.24} & \multicolumn{2}{|c|}{2.78} & \multicolumn{2}{|c|}{97.1} & & & & \\
\hline \multicolumn{10}{|c|}{ Açaí palm trees } & & \\
\hline & $\mathrm{N}$ & $\mathrm{P}$ & K & $\mathrm{Ca}$ & $\mathrm{Mg}$ & $\mathrm{S}$ & $\mathrm{B}$ & $\mathrm{Cu}$ & $\mathrm{Fe}$ & $\mathrm{Mn}$ & $\mathrm{Zn}$ \\
\hline \multicolumn{12}{|c|}{$\mathrm{g} \mathrm{kg}^{-1}$} \\
\hline & 19.4 & 1.79 & 8.96 & 4.89 & 0.94 & 3.24 & 47.2 & 5.4 & 347.4 & 218.9 & 25.8 \\
\hline
\end{tabular}


Excess B causes reductions in the productivity of agricultural areas, including the United States, Australia and South Africa (AQUEA et al., 2012; KAYIHAN et al., 2016). The increase in the contents of $B$ in the soil decreased the seed production of three of the four soybean varieties grown in Turkey (HAMURCU et al., 2019). The yield of cauliflower plants was favored up to a dose of $5 \mathrm{~kg} \mathrm{ha}^{-1}$, but negatively affected with higher doses (NAZIR et al., 2019). In Brazil, peanut productivity showed a reduction in response to higher doses of $\mathrm{B}$ via leaf (MANTOVANI et al., 2013). In northeast of Pará, the highest doses of $\mathrm{B}$ caused less production of dry mass of the aerial part and inflorescence in cauliflower plants (Brassica sylvestris (L.) Mill.) (PEREIRA et al., 2016).

The estimated $\mathrm{B}$ content that provided the highest productivity was $14.9 \mathrm{mg} \mathrm{kg}^{-1}$, corresponding to $5479 \mathrm{~kg}$ $\mathrm{ha}^{-1}$ year $^{-1}$, while the critical level was $13.2 \mathrm{mg} \mathrm{kg}^{-1}$ (Figure $3 \mathrm{~B})$. The proximity between these values demonstrates the need for careful management of fertilization with $\mathrm{B}$, as this can influence productivity or even higher costs, providing luxury consumption and/or causing phytotoxicity. The levels of $\mathrm{B}$ in the leaves showed linear behavior and increased $(p<0.05)$ from 12.0 to $17.6 \mathrm{mg} \mathrm{kg}^{-1}$ due to the fertilization with B (Figure 4), which made it impossible to find a maximum content of leaf B. At the doses of 40 and $60 \mathrm{~g} \mathrm{clump}^{-1}$, the highest leaf contents caused a reduction in productivity, but no visual symptoms of toxicity were observed. Contents close to the highest value obtained in the present study were observed in leaves of young açaí plants cultivated under greenhouse conditions, which reached $18 \mathrm{mg} \mathrm{kg}^{-1}$ (VIÉGAS et al., 2008). On the other hand, in açaí cultivated with fertigation, the levels of B in the leaves varied from 47 to $57 \mathrm{mg} \mathrm{kg}^{-1}$ as a function of fertilization with $13 \mathrm{~g}$ of $\mathrm{B}$ clump $^{-1}$ year $^{-1}$ via boric acid extraction (RIBEIRO, 2017). Higher levels of B, when applied via fertigation, are possibly related to more fractional application and greater availability of water in the summer, due to irrigation, which increases absorption efficiency.

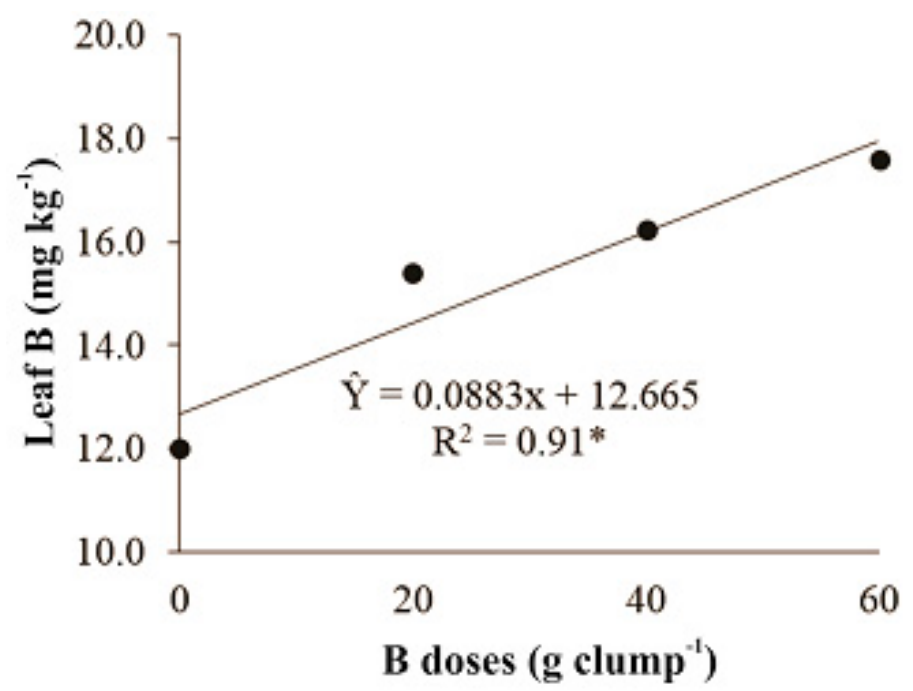

Figure 4. Leaf B content in irrigated açaí palm trees submitted to fertilization with B in the municipality of Tomé-Açu, northeastern Pará. *Significative $(p<0.05)$.

Studies in the state of Pará revealed levels of nearly $30 \mathrm{mg} \mathrm{kg}^{-1}$ in leaves of oil palm samples (MATOS et al., 2016) and 15 to $20 \mathrm{mg} \mathrm{kg}^{-1}$ in coconut leaves (SALDANHA et al., 2017) in productive phase. In soils of Kerala, India, the critical variation of B was 7.50 to 13.27 $\mathrm{mg} \mathrm{kg}^{-1}$ in the leaves of coconut trees (MATHEW et al., 2018). Under field conditions, in the state of Pará, the leaf contents considered ideal for the açaí tree are empirically based, following the references of other palm trees or based on the leaf contents in high productivity açaí trees (RIBEIRO, 2017).
The analysis of variance indicated that fertilization with $B$ did not influence $(p<0.05)$ the levels of macro and micronutrients in the plants, even when the levels of B in the plants were higher (Table 3). The levels observed for macro and micronutrients are within the range of values considered adequate for the açaí tree estimated by Araújo et al. (2016) and Ribeiro (2017), considering higher productivity, except for $\mathrm{Fe}$ and $\mathrm{Mn}$, in the last study, in which the values were lower due to the lower contents of $\mathrm{Fe}$ and $\mathrm{Mn}$ in the soil. 
Table 3. Nutrient content in leaves of fertigated açaí palm trees submitted to fertilization with B.

\begin{tabular}{|c|c|c|c|c|c|c|c|c|c|}
\hline & \multicolumn{6}{|c|}{ Macronutrients } & \multicolumn{3}{|c|}{ Micronutrients } \\
\hline & $\mathbf{N}$ & $\mathbf{P}$ & $\mathbf{K}$ & $\mathbf{C a}$ & Mg & $\mathbf{S}$ & $\mathbf{F e}$ & Mn & Zn \\
\hline g clump $^{-1}$ & \multicolumn{7}{|c|}{$\mathrm{g} \mathrm{kg}^{-1}$} & \multicolumn{2}{|c|}{$\mathrm{mg} \mathrm{kg}^{-1}$} \\
\hline 0 & 16.8 & 1.4 & 9.9 & 5.85 & 0.94 & 0.05 & 143 & 55.2 & 22.6 \\
\hline 20 & 18.8 & 1.4 & 8.8 & 7.8 & 1 & 1.32 & 153 & 44.6 & 30.6 \\
\hline 40 & 18 & 1.48 & 9.4 & 7 & 2.56 & 1.42 & 137 & 55.8 & 25.6 \\
\hline 60 & 17.4 & 1.48 & 9.6 & 6.5 & 1.02 & 1.24 & 158 & 61.2 & 23.6 \\
\hline \multicolumn{10}{|l|}{ Significance } \\
\hline Linear & ns & ns & ns & ns & ns & ns & ns & ns & ns \\
\hline Quadratic & ns & ns & ns & ns & ns & ns & ns & ns & ns \\
\hline
\end{tabular}

When comparing with the coconut culture, the levels of $\mathrm{N}, \mathrm{P}$ and $\mathrm{Mg}$ are close to what is considered ideal (SALDANHA et al., 2017), taking the fourth leaf as a reference. On the other hand, $\mathrm{S}$ and $\mathrm{K}$ are below the levels found for coconut, which may be related to high rainfall in the collection period, which causes leaching of nutrients, reducing absorption. Ca contents are above the values considered ideal for coconut cultivation.

The contents of $\mathrm{B}$ and other micronutrients in the soil were not influenced by the doses (Table 4). In açaí plants fertilized via fertigation, Ribeiro (2017) observed similar average values in soil of similar texture and in areas with high productivity. However, the values are lower than what is considered appropriate for other cultures (RAIJ et al., 1997; OLDONI et al., 2018). The low concentrations in the soil when compared to other crops can be explained by the average texture and rainfall above $600 \mathrm{~mm}$ in the period in which B application was carried out, as well as in the sampling period. The high rainfall, associated with the sandy texture of the soil, favor the leaching of B to deeper layers, decreasing the concentration in the collection layer.

Table 4. Micronutrient contents in soils of area cultivated with fertigated açaí palm trees according to B fertilization.

\begin{tabular}{cccccc}
\hline $\begin{array}{c}\text { B } \\
\text { g clump }^{-1}\end{array}$ & $\mathbf{B}$ & $\mathbf{C u}$ & $\begin{array}{c}\mathbf{F e} \\
\mathrm{mg} \mathrm{dm}^{-3}\end{array}$ & $\mathbf{M n}$ & $\mathbf{Z n}$ \\
\hline 0 & 0.22 & 2.64 & 146.4 & 21.6 & 1.86 \\
20 & 0.18 & 3.20 & 118.2 & 32.2 & 2.1 \\
40 & 0.14 & 3.56 & 111.6 & 35.4 & 1.72 \\
60 & 0.18 & 2.48 & 114.8 & 38.8 & 2.0 \\
\hline Significance & & & & & \\
\hline Linear & $\mathrm{ns}$ & $\mathrm{ns}$ & $\mathrm{ns}$ & $\mathrm{ns}$ & $\mathrm{ns}$ \\
Quadratic & $\mathrm{ns}$ & $\mathrm{ns}$ & $\mathrm{ns}$ & $\mathrm{ns}$ & $\mathrm{ns}$ \\
\hline
\end{tabular}

${ }^{\mathrm{ns}}$ Not significative $(p<0.05)$.

Boron leaching in the soil has also been observed in other studies (ROSOLEM; BISCARO, 2007; OLIVEIRA et al., 2009), justified by the high rainfall that occurred in a medium texture soil, low organic matter content and low $\mathrm{pH}$. These results help to understand the non-occurrence of symptoms, because when B is added to the soil a large part can be lost by leaching. Boron toxicity is associated with the application of doses higher than $3 \mathrm{~kg}$ of $\mathrm{B} \mathrm{ha}^{-1}$, in a single application or very localized around the plants, cases in which symptoms are usually observed, but which quickly disappear due to leaching. In the present study, in a single application, the equivalent of $8 \mathrm{~kg}$ of hawas used in the treatment of the highest dose, with no symptoms of toxicity in the leaves being identified. The main consequence evidenced was the drop in productivity with doses higher than $30 \mathrm{~g}$ clump ${ }^{-1}$.
The economic analysis was performed considering the costs of fertilizer and fruit production in the control treatment and in the one with the highest productivity. The difference between the treatment of higher production and the control was $1756 \mathrm{~kg} \mathrm{ha}^{-1}$. As the expenditure on the purchase of fertilizer was $170 \mathrm{~kg}$ of fresh fruits, the net production was $1586 \mathrm{~kg} \mathrm{ha}^{-1}$, which corresponds to a $42 \%$ increase in net yield of fresh fruit.

\section{Conclusion}

The highest productivity of fresh açaí fruits was achieved with the dose of $20 \mathrm{~g}$ of B clump ${ }^{-1}$, corresponding to $5521 \mathrm{~kg} \mathrm{ha}^{-1}$. The content considered adequate, providing the highest productivity, was $14.9 \mathrm{mg} \mathrm{kg}^{-1}$, while the critical level was $13.2 \mathrm{mg} \mathrm{kg}^{-1}$. These results 
indicate that higher doses of $\mathrm{B}$, in addition to reducing productivity, can cause phytotoxicity. The increase in the production of fresh fruits represented a net gain of $42 \%$. The results found in the present study provide important information for producers, allowing the application of B at appropriate levels to obtain high productivity, reducing the quantities that have been currently applied.

\section{Acknowledgement}

We thank Capes for the first author's scholarship and CNPQ for the last author's productivity scholarship.

\section{References}

AQUEA, F.; FEDERICI, F.; MOSCOSO, C.; VEGA, A.; JULLIAN, P.; HASELOFF, J.I.M.; ARCE $\square$ JOHNSON, P.A molecular framework for the inhibition of Arabidopsis root growth in response to boron toxicity. Plant, Cell \& Environment, Oxford, v.35, n.4, p.719-734, 2012.

ARAUJO, F. R. R.; VIÉGAS, I. J. M.; CUNHA, R. L. M.; VASCONCELOS, W. L. F. Nutrient omission effect on growth and nutritional status of assai palm seedlings. Pesquisa Agropecuária Tropical, Brasília, DF, v.46, n.4, p.374-382, 2016.

BROSCHAT, T. K. Boron deficiency in palms. Gainesville: University of Florida, 2007. Disponível em: http://horttech.ashspublications.org/content/19/4/690.full. Acesso em: 10 nov. 2017.

BRUNES, A.P.; MENDONÇA, A.O.; OLIVEIRA, S.; LEMES, E.S.; LEITZKE, I.D.; VILLELA, F.A. Produção, qualidade e expressão isoenzimática de semente de trigo produzidas sob diferentes doses de boro. Revista Brasileira de Biociências, Porto Alegre, v.14, n.3, p.137144, 2016.

CRAVO, M.S.; VIÉGAS, I.J.M.; BRASIL, E. Recomendações de adubação e calagem para o estado do Pará. Belém: Embrapa Amazônia Oriental, 2007. $262 \mathrm{p}$.

HAMURCU, M.; ARSLAN, D.; HAKKI, E.E.; OZCAN, M.M.; PANDEY, A.; KHAN, M.K.; GEZGIN, S. Boron application affecting the yield and fatty acid composition of soybean genotypes. Plant, Soil and Environment, Praga, v.65, n.5, p.238-243, 2019.
HOMMA, A.K.O.; NOGUEIRA, O.L.; MENEZES, A.J.E.A.; CARVALHO, J.D.; NICOLI, C.M.L.; MATOS, G.D. Açaí: novos desafios e tendências. Amazônia: Ciência \& Desenvolvimento, Belém, v.1, n.2, p.7-23, 2006.

IBGE - Instituto Brasileiro de Geografia e Estatística. Levantamento sistemático da produção agrícola paraense (LSPA/IBGE). Belém: IBGE, 2017.

INMET - Instituto Nacional de Meteorologia. Banco de dados meteorológicos para ensino e pesquisa. Brasília, DF, 2019. Disponível em: http://www.inmet.gov.br/portal/ index.php?r=bdmep/bdmep.Acesso em: 18 dez. 2019.

JARDIM, M.A.G.; ANDERSON, A.B. Manejo de populações nativas de açaizeiro no estuário amazônicoresultados preliminares. Boletim de Pesquisa Florestal, Colombo, v.15, p.1-18, 1987.

KAYIHAN, D. S.; KAYIHAN, C.; ÇIFTÇI, Y. Ö. Excess boron responsive regulations of antioxidative mechanism at physio-biochemical and molecular levels in Arabidopsis thaliana. Plant Physiology and Biochemistry, Paris, v.109, p.337-345, 2016.

MALAVOLTA, E.; VITTI, G. C.; OLIVEIRA, S. A. Avaliação do estado nutricional das plantas: princípios e aplicações 2.ed. Piracicaba: Potafos, 1997. 319 p.

MANTOVANI, J. P.M.; CALONEGO, J. C.; FOLONI, J. S. S. Adubação foliar de boro em diferentes estádios fenológicos da cultura do amendoim. Revista Ceres, Viçosa, MG, v.60, n.2, p.270-278, 2013.

MARSCHNER, P.Mineral nutrition of higher plants. $3^{\text {rd }}$ ed. New York: Academic Press, 2012. 672 p.

MASOOD, S.; ZHAO, X. Q.; SHEN, R. F. Bacillus pumilus increases boron uptake and inhibits rapeseed growth under boron supply irrespective of phosphorus fertilization. AoB Plants, Oxford, v.11, n.4, p.1-10, 2019.

MATHEW, J.; KRISHNAKUMAR, V.; SRINIVASAN, V.; BHAT, R.; NAMBOOTHIRI, C.G.N.; HARIS, A.A. Standardization of critical boron level in soil and leaves of coconut palms grown in a tropical Entisol. Journal of Soil Science and Plant Nutrition, Temuco, v.18, n.2, p.376-387, 2018.

MATOS, G.S.B.; FERNANDES, A.R.; WADT, P.G.S. Níveis críticos e faixas de suficiência de nutrientes derivados de métodos de avaliação do estado nutricional da palma-de-óleo. Pesquisa Agropecuária Brasileira, Brasília, DF, v.51, n.9, p.1557-1567, 2016. 
NAZIR, G.; KUMAR, P.; SHUKLA, A.K.; SHARMA, $U$. Influence of boron fertilization on cauliflower productivity, nutrient uptake and soil nutrient status in an acid Alfisol in Northwestern Himalaya. Communications in Soil Science and Plant Analysis, Basingstoke, v.50, n.12, p.1403-1416, 2019.

OLDONI, F.C.A.; LIMA,A.M.N.; CAVALCANTE, Í.H.L.; SOUSA, K.S.M.; CARNEIRO, M.A.; CARVALHO, I.R.B.D. Boron fertilizing management on fruit production and quality of mango cv. Palmer in semiarid. Revista Brasileira de Fruticultura, Jaboticabal, v.40, n.3, p.1-8, 2018.

OLIVEIRA, M.; DE CARVALHO, J. E. U.; NASCIMENTO, W. M. O.; MULLER, C. H. Cultivo do açaizeiro para produção de frutos. Belém: Embrapa Amazônia Oriental, 2002. 18 p. (Circular técnica)

OLIVEIRA, M.S.P.; LEMOS, M.A.; SANTOS, E.O.; SANTOS, V.F. Variação fenotípica em acessos de açaizeiro (Euterpe oleracea Mart.) para caracteres relacionados à produção dos frutos. Belém: EmbrapaCPATU, 1998. 23p.

OLIVEIRA, N.W.; MUNIZ, S.A.; SILVA, G.A.M.; CASTRO, C.; BORKERT, M.C. Boron extraction and vertical mobility in Paraná State Oxisol, Brazil. Revista Brasileira de Ciência do Solo, Viçosa, MG, v.33, n.5, p.1259-1267, 2009.

PEREIRA, M.E.; LIMA JUNIOR, J.A.D.; SOUZA, R.O.D.M.; DE GUSMÃO, S.A.; LIMA, V.M. Irrigation management influence and fertilizer doses with boron on productive performance of cauliflower. Engenharia Agrícola, Jaboticabal, v.36, n.5, p.811-821, 2016.

PRADO, R. D. M. Nutrição de plantas. São Paulo: Editora UNESP, 2008. 407 p.

RAIJ, B. V.; CANTARELLA, H.; QUAGGIO, J. A.; FURLANI, A. M. C. Recomendações de adubação e calagem para o estado de São Paulo. Campinas: Instituto Agronômico, 1997. 285 p.

RIBEIRO, F. O. Estado nutricional e produtividade de açaizeiro fertirrigado em função variabilidade espacial. 2017. Dissertação (Mestrado em Agronomia) - Instituto de Ciências Agrárias, Universidade Federal Rural da Amazônia, Curió Utinga. 2017.

ROSOLEM, C.A.; BISCARO, T. Adsorção e lixiviação de boro em Latossolo Vermelho-Amarelo. Pesquisa Agropecuária Brasileira, Brasília, DF, v.42, n.10, p.1473-1478, 2007.
SALDANHA, E.C.M.; SILVAJUNIOR, M.L.D.; LINS, P.; PONTES, M.; FARIAS, S.C.C.; WADT, P.G.S. Nutritional diagnosis in hybrid coconut cultivated in northeastern Brazil through diagnosis and recommendation integrated system (DRIS). Revista Brasileira de Fruticultura, Jaboticabal, v.39, n.1, p.1-9, 2017.

SANTOS, H.G.; JACOMINE, P.K.T.; DOS ANJOS, L.H.C.; DE OLIVEIRA, V.A.; LUMBRERAS, J.F.; COELHO, M.R.; ALMEIDA, J.A.; ARAÚJO FILHO, J.C.; OLIVEIRA, J.B.; CUNHA, T. Sistema brasileiro de classificação de solos. 5.ed. Brasília: Embrapa, 2018. $356 \mathrm{p}$.

SEDAP - Secretaria de Estado de Desenvolvimento Agropecuaria e da Pesca. Acaí. Disponível em: http:// www.sedap.pa.gov.br/?q=content $/ \mathrm{a} \% \mathrm{C} 3 \% \mathrm{~A} 7 \mathrm{a} \% \mathrm{C} 3 \% \mathrm{AD}$. Acesso em: 17 mai. 2018.

SILVA, F.C. Manual de análises químicas de solos, plantas e fertilizantes. 2.ed. Brasília: Embrapa Informação Tecnológica, 2009. $627 \mathrm{p}$.

SOBRAL, F. L. Nutrição e adubação do coqueiro. In: FERREIRA, J.M.S.; WARWICK, D.R.N.; SIQUEIRA, L.A. (ed.). A cultura do coqueiro no Brasil. Aracaju: EMBRAPA-SPI, 1998. p.129-157.

STATSOFT. Statistica for Windows - Computer program manual. Tulsa, 2009.

VIÉGAS, I. J. M.; FRAZÃO, D. A. C.; THOMAZ, M. A. A.; CONCEIÇÃO, H. E. O.; PINHEIRO, E. Limitações nutricionais para o cultivo de açaizeiros em Latossolo Amarelo textura media, Estado do Pará. Revista Brasileira de Fruticultura, Jaboticabal, v.26, n.2, p.382384, 2004.

VIÉGAS, I. J. M.; GONÇALVES, A. A. S.; FRAZÃO, D. A. C.; CONCEIÇÃO, H. E. O. Efeito das omissões de macronutrientes e Boro na sintomatologia e crescimento de plantas de açaizeiros (Euterpe oleracea Mart.). Revista de Ciências Agrárias, Belém, v.50, n.1, p.129-142, 2008.

VIÉGAS, I.J.M.; MEIRELES, R.O.; FRAZÃO, D.A.C.; CONCEIÇÃO, H.E.O. Avaliação da fertilidade de um Latossolo Amarelo textura média para o cultivo do açaizeiro no estado do Pará. Revista de Ciências Agrárias, Belém, v.52, n.1, p.23-36, 2009. 